\title{
An Analysis of Effectiveness of Popularization of Marxism in the Ideological and Political Theory Course Teaching in Universities
}

\author{
Li Kang, Mengyan Feng and Li Liu \\ Institute of Marxism, Southwest University, Chongqing 400715, China
}

\begin{abstract}
Effectiveness of popularization of Marxism in ideological and political theory course is the key for Chinese university students to set up a correct outlook on world, a correct outlook on life and values. As a result of influences of all kinds of factors, there still exist a lot of issues and difficulties in the process of publicizing and educating Marxism in Chinese universities. This requires taking corresponding measures to fulfill popularization of Marxism in ideological and political theory course teaching in universities.
\end{abstract}

Key Words: Ideological and political theory course, popularization of Marxism, effectiveness

\section{Importance of Popularization of Marxism in Ideological and Political Theory Course Teaching}

As an important battlefield for popularization of Marxism, universities have a compelling obligation and mission in carrying forward popularization of Marxism. The ideological and political theory course in universities is the key to publicize the theoretical policies and strategies of the Communist Party of China. The CPC has, throughout, been attaching great importance to construction of the ideological and political theory course in universities which has become a major channel for carrying forward popularization of Marxism.

\section{Universities are an important battlefield for popularization of Marxism}

As an important base that cultivating qualified constructors and reliable successors for the cause of socialism with Chinese characteristics, universities burden the heavy historical task of socialist education and ideological and political education on young students. Universities have their particular advantages in research of Marxism theory. On one hand, they have theoretical practitioners who have profound theoretical foundation. This provides security for research of Marxism theory and lays theoretical foundation for its popularization.

Research project (key) of education and teaching reform in Southwest University and achievement of "Study on Popularization of Marxism in Ideological and Political Theory Course Teaching in Universities" (NO: 2010JY041)
On the other hand, universities have a vast number of young students who have knowledge in Marxism theory. Currently, there are more than 20 million university students in China who, without doubt, are an important carrier for popularization of Marxism. In the meantime, they are also an important power in building a comprehensive well-off society and realizing development of the country through science and education and the strategy of reinvigorating the country through human resource development. Therefore, it is absolute advantage to publicize Marxism in universities.

Ideological and political theory course in universities provides theoretical support for popularization of Marxism

Ever since the reform and opening up, several major turns of adjustment and reform have been made to the ideological and political theory courses in universities of China, which gradually become perfect. Especially, the proposal of the "05 Project" has made the ideological and political theory course more comprehensive and scientific. These courses start out from the ideological reality of university students and popularize and publicize Marxism theory to university students from different perspectives. As an important publicity channel for Marxism theory, the ideological and political theory course in universities ought to become an important carrier for popularization of Marxism. The ideological and political theory courses in universities not only have systematic teaching materials to publicize Marxism theory, but also have 
a teacher faculty which specially engages in research of Marxism theory. All the above provides security for research of Marxism.

\section{Issues Existing in the Process of Popularization of Marxism in Ideological and Political Theory Course Teaching in Universities}

In the process of popularization of Marxism, the ideological and political theory courses in universities have played a decisive role and have achieved an obvious effect. However, there still exist some educational issues and difficulties in popularization of Marxism in teaching, which is mainly manifested in the following several aspects.

\section{Issues existing in terms of students}

\section{Deficiency of University Students' Belief in Marxism}

"Belief is respect toward a certain theory, thought or doctrine in the depth of the heart and to regard it as the guidance for one's action." (Note 1) As a result of invasion of all kinds of western thoughts and cultures, university students come into doubt and disbelief in Marxism. Individualism, money worship and hedonism prevail. In the eyes of university students, Marxism has been out of date and has no long adapted to the society in which money occupies a top position. Today, a large majority of people are more willing to pursue direct realistic interest instead of trusting Marxism, let alone belief. Thus, a large part of university students hold such a view that the ideological and political theory course is not much necessary, which will certainly affect popularization of Marxism in universities.

Low interest in learning by university students in Marxism theory

Since abstractness of the theory of Marxism is strong and the realistic function of the theory is not that obvious, there is certain difficulty in comprehension of students. In addition, a large majority of universities adopt the teaching mode of "large class", this causes students lack interest in learning Marxism.

\section{Issues existing in terms of teachers}

Low theoretical quality of teachers teaching ideological and political theory course

The theoretical level and quality of teachers teaching ideological and political theory course in universities determines the degree of fulfillment of popularization of Marxism. With increasing expansion of enrollment in universities, rapid increase of the number of university students is seen. This leads to intense shortage of teachers, especially teachers teaching the basic discipline of the ideological and political theory course. For the need of teaching, quite a large number of teachers who graduate from non-Marxism theory majors are "invited" into the team of the ideological and political theory course teaching. This causes the theoretical level of teachers teaching the ideological and political theory course to be uneven and the teaching effect to be different. Meanwhile, due to the heavy teaching task, quite a lot of teachers have no energy to devote themselves into scientific research and their theoretical level gets constrained.

Serious Issues Existing in the Teaching Method of Teachers Teaching Ideological and Political Theory Course

In the class of ideological and political theory course, doctrinism and formalism are serious. Teachers blindly repeat what the book says and impart dead knowledge in the teaching materials. They fail to teach according to the current hot social events. As a result, connection between theory and reality is not enough and what exists between teachers and students is only a kind of relationship of teacher who teachers and student who listens and communication is lacking between them.

\section{Issues existing in terms of universities}

Universities have no sufficient investment in the research grant for Marxism theory.

This restrains a large number of teachers engaged in research of Marxism theory in terms of educational training, material allocation and professional evaluation, etc. The phenomenon of cutting down the class hours of political theory courses is common in universities. A lot of universities adopt the teaching mode of large class in order to economize costs, as a result of which the classroom discipline management is slack and the phenomenon of playing truant by students is serious.

The universities fail to build a campus culture environment for popularization of Marxism.

At the working conference strengthening and improving the ideological and political education among university students, the former Chinese President $\mathrm{Hu}$ Jintao mentioned, "Common support from all walks of life in the society is needed for establishment of university students' ideal and belief, 
cultivation of their ideological quality, cultivation of their moral sentiments, formation of their civilization habit and shaping of their beautiful soul. It is necessary to build a healthy and positive social environment, especially a perfect cultural environment, public opinion environment and surrounding campus environment." (Note 2) In the past several year, network has become a necessity in the life of university students. Nevertheless, network is a "complex cylinder" where a variety of information is mixed up. Since network cultural construction in universities is relatively laggard which is in disharmony with the demand of university students in a new period, the platform of campus network culture is unlikely to give full play to its functions. As a result, the campus cultural environment is not made full use of and popularization of Marxism merely exists in the classroom. This is neither able to popularize Marxism among the vast majority of university students nor able to make popularization of Marxism attain its anticipated effect and objective.

\section{Measures for Effectiveness of Popularization of Marxism in Ideological and Political Education Course Teaching in Universities}

\section{Content of Marxism theory in itself should be popularized}

Combining Marxism theory with daily life of university students

Marxism theory is a scientific theory on human development rules. It is relatively abstract, so it has to be popularized and adaptable to life in order to play its powerful theoretical guiding role. Only connected with the life reality of students, can Marxism theory reflect its value connotation and play its role as an ideological weapon. Contemporary university students are the subject to popularize Marxism in universities. Therefore, in order to realize popularization of Marxism in universities, it is necessary to resolve the realistic life issues of university students to let them voluntarily accept education and edification of Marxism theory and personally experience the practical applicability of Marxism theory. This can consolidate their belief in Marxism and make Marxism theory possess more vitality in the classroom.

The abstract language of Marxism theory needs to be visualized and popularized

As a theoretical doctrine in the western society, Marxism employs a language hard to understand.
Therefore, the first to do is to convert the language in order for Marxism theory to enter the teaching materials and classroom of Chinese universities and to enter the brain of university students. In ideological and political theory courses, teachers have to convert the recondite professional technical terms of Marxism theory into a teaching language students are delighted to accept with an expression mode favored by students. This reduces the barrier of students in learning Marxism theory and prevents them from being fed up with learning Marxism theory. This is also more helpful for students to comprehend and master the teaching content in the classroom, accept Marxism at the bottom of their heart, appreciate the vitality of Marxism theory and experience a delighted feeling at heart.

Universities should strengthen construction of ideological and political theory course

Enlarging fund investment in ideological and political theory course and strengthening construction of the teachers team

It is necessary to enlarge fund investment in construction of the teachers' team. Teachers teaching the ideological and political theory course ought to share an equal opportunity as teachers involved in other disciplines in terms of application of the research subject, further study and professional evaluation and share similar treatment in terms of salary and welfare. Instead, they should not get excluded or discriminated. In this way, they are likely to devote more to research and teaching to construct a high quality and professional teachers' team with lofty teacher morality, exquisite skills, rational structure and full vigor and to provide a guarantee for education and publicity of Marxism in universities.

Strengthening construction of campus cultural environment

Universities ought to carefully study Marxism theory and skillfully integrate it into construction of the campus environment. For example, they may put up posters everywhere in the campus to enable the extensive majority of teachers and students to experience education of Marxism. In addition to construction of the material form, construction of spiritual culture is also an important component of construction of campus culture. A good school spirit is able to bring an invisible feeling of constraint to repress immoral style in the campus. In the meantime, it can bring a power to stimulate the will to struggle. A good school spirit is the key to popularize Marxism in universities. To a large extent, 
it is able to stimulate students' interest in learning Marxism theory and consciously internalize it into action, which effectively promotes popularization of Marxism. Thus, it is necessary to vigorously play the role of campus cultural environment as a carrier, so as to widely publicize and popularize Marxism theory.

\section{Innovating teaching mode and method of ideological and political theory course and improving teaching content}

Teaching method is to resort to certain teaching means to impart to students with an appropriate teaching method. In order for Marxism theory to be popularized, it is necessary to make improvement and innovation on the former teaching mode and to make teaching more pertinent and effective.

Innovating teaching method and means of ideological and political theory course

Firstly, it is necessary to change the traditional teaching mode and eliminate the teaching mode of "cramming education". To this end, teachers are supposed to take full consideration of the psychological features of contemporary university students, adopt multiple teaching methods, such as, the mode of interaction between teachers and students, problem heuristic mode and so on, effectively guide students to ponder over the issue of popularization education of Marxism, lead students in independent reflection on their own issues, make theoretical innovation and theoretical development on popularization of Marxism, encourage students to deeply learn the Marxism thought system, scientifically direct students to flexibly apply Marxism thought and shape students' scientific outlook on life, outlook on value and outlook on world. Then, it is necessary to adopt multimedia assisted teaching. Teachers can make a PPT to present such elements as word, picture, chart and video, etc., and make the originally sterile political theory course full of vitality. For instance, in the course "An introduction to Mao Zedong thought and the theoretical system of socialism with Chinese characteristics", when talking about the experience of Deng Xiaoping, it is a good choice for teachers to broadcast the full-length documentary "Deng Xiaoping" to students. In the course "Ideological and Moral Cultivation and Legal Basis", when talking about patriotism education, it is a good choice for teachers to broadcast the video of the World Cup to attract the attention of students and to fully mobilize interest of students in learning. Nevertheless, teachers should not depend too much on multimedia.
Otherwise, they may not receive the anticipated effect. Publicity of Marxism should not only be done in the classroom, but should also be extended outside the classroom. Modern university students almost have a notebook computer per capita, so the universities and teachers may make full use of this network platform. For example, the Southwest University makes full use of campus network and uploads relative knowledge links of the ideological and political theory course to the campus network. This enables students to $\log$ in the school website for learning. Of course, it is also possible for teachers to have communication with students by means of Tencent and Microblog, etc., to know more about the ideological confusion of students. Also, students may resort to these carriers to search for assistance from teachers so as to make publicity of Marxism more extensive.

Improving the teaching content and focusing on connection of theory with reality

The ideological and political theory course in universities contains four compulsory courses, which publicize Marxism from different perspectives and which cultivate and educate university students in terms of Marxism belief. Teachers integrate the content of the teaching material in accordance with the acceptance capacity of students and highlight the emphasis in teaching. For example, in the course "An introduction to Mao Zedong thought and the theoretical system of socialism with Chinese characteristics", teachers might combine the current hot social issues, the new policies of the nation and the latest frontier issues of the contemporary disciplines, integrate their content into several major special subjects, synthesize learning of theory with analysis of current social issues and connect theory with reality. In the process of studying the Marxism theory, students may resolve realistic social issues with their own standpoint, viewpoint and method and cultivate their ability to apply a theory to analyze and resolve a problem under unconscious influences. In addition, implementation of popularization of Marxism also clamors for participation of social practice. For instance, the universities may organize an activity of "Red Tour", lead students to pay a visit and to learn in Yan'an and let them personally experience the magic of Yan'an spirit. In the process of the tour, it is a good choice for teachers to publicize Marxism among students in due course. This helps to make students have a favorable impression on Marxism and to attain the effect of publicizing and educating Marxism both in and out of the classroom. 
Students should give full play to their subjective initiative and consciously learn and practice Marxism theory

In the universities, the vast majority of university students are the target of popularization. Thus, in the classroom it is not enough for only teachers to act as "a monodrama", active participation of students is also required and their subjective initiative should be fully played. Popularization of Marxism in this way can achieve an anticipated effect. In addition to learning of Marxism in the classroom, the university students should also consciously cultivate the Marxism theory quality in the daily life so as to consolidate their belief in Marxism, combine the Marxism theory with the construction of modernization, do their little bit to the building of a well-off society and fulfill their own life value

Strengthening the effectiveness of the ideological and political theory course is the only road for popularization of Marxism. Therefore, fulfillment of popularization of Marxism needs to make adjustment and reform from all links in the teaching. In the pertinent teaching, teachers should ask students to play their subjective initiative to make the teaching content in the classroom to effectively enter the brain and soul of students. Only in this way, can the ideological and political theory course in universities more effectively realize popularization and can effectiveness of the ideological and political theory course be achieved.

\section{Notes}

1. Wang, Ze. Some Considerations about the Innovation of Ideal and Faith Education in the New Period. Journal of China Executive Leadership Academy Jinggangshan, 2008, (5).

2. Selection of the Important Documentations since the 16th Congress (Volume 2). Central Party Literature Press, 2006:645.

\section{References}

Chen, Jin. (2011). Popularization of Marxism on the Base of Ideological and Political Theory Course. Economic Research Guide, (4).

Fu, Xiaohua, \& Xie, Zhenping. (2011). Present situation of university ideological and political teachers' self-efficacy and career management- An analysis of questionnaire survey on ideological and political teachers at 8 universities in Fujian. Journal of Fujian Agriculture and Forestry University (Philosophy and Social Sciences), (2).

Li, Donghua. (2011). Popularization of Contemporary Marxism and Ideological and Political Theory Course in Universities. Heihe Journal, (8)

Li, Xiaoping. (2010). Analysis and Consideration of Strengthening the Effectiveness of Ideological and Political Theory Course Teaching in Universities. Academic Forum, (10).

Li, Yaru, \& Zhao, Xuefeng. (2012). The Function of Ideological and Political Theory Course in Universities as a Carrier in Popularization of Marxism. Studies In Ideological Education, (5).

Pan, Jing. (2011). An Analysis of the Dialectical Relationship between Popularization of Marxism and Ideological and Political Theory Course in Universities. Guangxi Social Sciences, (8). 